\section{CHEMICAL REACTIVITY AND STATE OF TRYPTOPHAN RESIDUES IN NEOCARZINOSTATIN UNDER PHYSIOLOGICAL CONDITION}

\author{
Hiroshi MAEda \\ Department of Microbiology, Kumamoto \\ University Medical School \\ Kumamoto, Japan
}

(Received for publication August 24, 1973)

Neocarzinostatin (NCS) ${ }^{a}$ is an antitumor antibiotic protein of which primary structure was reported by this author et al. recently.1,2) It possesses 109 amino acid residues (molecular weight; about 11,000 ) including two tryptophan, one tyrosine, one lysine, three arginine and two disulfide bridges. But no methionine nor histidine residue was found. The conformational study of NCS in a physiological condition using ORD and $C D$ showed strong Cotron effects in $240 \sim 300 \mathrm{~nm}$ area, which were assigned to be due to the contributions of such residues as tyrosine, phenylalanine and possibly disulfide chromophores. The contribution of the tryptophan residues which located at the positions 46 and 79 , however, was not clear. ${ }^{3)}$ Furthermore, NCS molecule has been shown to have unusually tight gross structure and predominantly antiparallel $\beta$-structure. ${ }^{3)}$

In the present communication, I want to report the state of tryptophan residues in the physiological condition (isotonic and near neutral $\mathrm{pH}$ ) as judged by the chemical reactivity of tryptophan residue to o-nitrophenyl sulfenyl chloride $(\mathrm{NPS}-\mathrm{Cl})^{a)}{ }^{4)}$ NPS-Cl was chosen because of its high selectivity toward the tryptophan residue. ${ }^{4,52}$ Other tryptophan modifying reagents often react less selectively or less quantitatively. ${ }^{5)}$ For example, widely used Nbromosuccinimide is known to result in peptide bond cleavage and/or react less selectively other than tryptophan residue (eg. reaction with tyrosine etc. ${ }^{5,6,7)}$ ).

The reactivity of two tryptophans in NCS in the unfolded state (using $50 \%$ acetic acid or $8 \mathrm{~m}$ urea) has been shown previously that they

a) Abbreviations used, NPS: o-nitrophenylsulfenyl, NCS: neocarzinostatin. reacted with NPS-Cl quantitatively ${ }^{8)}$ within one hour as expected. The present study was carried out under a mild condition ${ }^{b 2}$ at $\mathrm{pH} 4.0 \sim 7.0$ where NCS was stable and as closely physiological as possible, using the buffer solution of DULBECCO's ${ }^{\theta)}$ in $0.01 \mathrm{M} \mathrm{Na}^{+-} \mathrm{K}^{+-}$phosphatebuffered $0.15 \mathrm{M} \mathrm{NaCl}$ solution. But $\mathrm{Ca}^{++}$and $\mathrm{Mg}^{++}$were eliminated from the buffer. NPS$\mathrm{Cl}$, three times crystallized from chloroform, was a generous gift of Dr. KAwAuchr of Hormone Research Laboratory, University of California, San Francisco. NCS, also a generous gift from Dr. Y. KoyAmA of Kayaku Antibiotic Research Laboratory, Tokyo, was used after chromatography with CM-cellulose as described in a previous report, ${ }^{10)}$ with a slight modification. Since NPS-Cl was not freely soluble in the buffer solutions used, the crystals of NPS-Cl were finely powdered before adding to the solutions containing NCS where NCS had an approximate concentration of $0.1 \sim 0.05$ $\mu \mathrm{mole} / \mathrm{ml}$. NPS-Cl was added to NCS solution at 53 100 molar excess ${ }^{c)}$ over NCS. The reaction mixture was kept under reciprocal shaking for 3 and 24 hours at $16 \sim 18^{\circ} \mathrm{C}$ and at $\mathrm{pHs} 4.0,5.26 .1$ and 7.0 respectively. The $\mathrm{pH}$ of each solution was readjusted with $0.15 \mathrm{M} \mathrm{HCl}$ or $0.2 \mathrm{M} \mathrm{NaH}_{2} \mathrm{PO}_{4}$ when it was necessary. The reaction was terminated by applying the supernatant of the reaction mixture, after centrifugation $(2,700 \mathrm{rpm}, 20 \mathrm{~min})$, on a column of Sephadex G-50 when biological activity should be assayed, or terminated by precipitation with a mixture of acetone and $1 \mathrm{M} \mathrm{HCl}(39: 1)$ followed by further washing as described in a previous paper $^{8)}$. The quantitation of NPS-chromophore in NCS was determined by spectrophotometry using $E=4,000$ at $365 \mathrm{~nm}^{4}$.

The present results in duplicates revealed that one tryptophan residue in NCS reacted readily with NPS-Cl at all pHs tested within 3 hours at $16 \sim 18^{\circ} \mathrm{C}$. This can be interpreted that this

b) Since NCS is stable in the acidic $\mathrm{pH}(<7)$, unfolding of the protein molecule should not be expected to occur.

c) Since NPS-Cl has not been dissolved completely in these buffers, the intrinsic concentrations of NPS-Cl were not known, but it should be lower than the values given here. 
residue is accessible to the reagent and thus can be considered being exposed outward on the surface of the molecule of NCS. The second tryptophan residue reacted with NPS-Cl gradually within 24 hours ${ }^{d)}$ at $16 \sim 18^{\circ} \mathrm{C}$. The numbers of NPS-chromophore after the reaction were 1.6 2.0/mole of NCS in all pHs tested. These results indicate that one of the tryptophan residues is exposed freely and the other to the lesser degree. The previous results of ORD and $\mathrm{CD}$ in which no tryptophan residue seemed to show typical CotTon effect in $\mathrm{NCS}^{3)}$ may be explained by the good to fair chemical reactivity of two tryptophan residues in physiological condition which was observed in the present experiments. Tyrosine residue on the contrary was chemically inert and exist as buried state ${ }^{3)}$.

The mono-NPS-derivative ${ }^{e)}$ of NCS showed bacteriocidal activity against Sarcina lutea at $0.4 \mu \mathrm{g} / \mathrm{ml}$. This fact indicates at least one tryptophan is not involved in the function of antibiotic activity. The bis-NPS-derivative of NCS was devoid of inhibitory activity to the growth of $S$. lutea. This indicates the important role of the second tryptophan residue for the structural integrity of active molecular conformation of NCS. Furthermore the biologically active mono-NPS-derivative may be expected to exert a different pharmacological properties such as increased permeability on cell membrane due to incorporation of a hydrophobic aromatic ring. Such modification of amino groups in NCS, bis-succinyl-NCS for instance, resulted in loss of cytocidal activity but retained cytostatic property ${ }^{11}$.

The author thanks for Dr. H. KAwAUCHI and Dr. Y. KOYAMA for their generous gifts of NPS-Cl and NCS respectively.

Note added in proof:

A similar result was obtained in our separate study $^{12)}$ and the tryptophan residue 79 was

d) As given in the Foot Note $c$ ), the time required for the completion of the reaction could be shorter, when given NPS-Cl could have been dissolved completely.

e) The bacteria, Sarcina lutea, is one of the most susceptible organism to NCS. A preliminary examination of the reaction product obtained after $3 \mathrm{hr}$ reaction at $\mathrm{pH} 7.0$ showed only one spot on electrophoresis at $\mathrm{pH} 8.2$ and thus it is considered as a single principle. found selectively oxidized with N-bromosuccinimide in $0.1 \mathrm{M} \mathrm{Na}$ phasphate buffer at $\mathrm{pH}$ 6.1

\section{References}

1) Maeda, H.; C.B. Glaser, K. Kuromizu \& J. MEIENHOFER: Structure of neocarzinostatin, an antitumor antibiotic protein. In the Proceedings of Symposium on Protein Structure (Tanpakushitsu Kozo Toron-Kai), Maebashi, Japan, Nov. Vol. 23: 9 12, 1972

2) Meienhofer, J.; H. Maeda, C. B. Glaser, K. Kuromizu \& J. Czombs: Primary structure of neocarzinostatin, an antitumor protein. Science 179: 875 876, 1972

3) Maeda, H.; H. Shiroishi, S. Onodera \& N. ISHIDA: Conformation of antibiotic protein, neocarzinostatin, studied by plane polarized infrared spectroscopy, circular dichroism and optical rotatory dispersion. Int. J. Peptide and Protein Res. 5: 19 26, 1973

4) SCOFFone, E.; A. Fontana \& R. Rocchi: Sulfenyl halides as modifying reagents for polypeptides and proteins. I. Modification of tryptophan residues. Biochemistry 7:971 979,1968

5) MAEDA, H.: Quantitation of tryptophan residues in proteins. Tanpakushitsu Kakusan Koso (Protein Nucleic Acid Enzyme) 17: 470 474, 1972

6) Ohno, T.; R. Yamamura, K. Kuriyama, H. INOUE \& Y. OKADA: Structure of N-bromosuccimide-modified tabacco mosaic virus protein and its function in the reconstitution process. Virology 50: 76 83, 1972

7) Fontana, A.: Methods in Enzymology. xxv: $419 \sim 423,1972$

8) Maeda, H. \& J. Meienhofer: On the tryptophan content of neocarzinostain. Int. J. Prot. Res. II: $135 \sim 136,1970$

9) Dullbecco, R. \& M. Vogt: Plaque formation and isolation of pure lines with poliomyelitis viruses. J. Explt. Med. 99: 167 182, 1954

10) Maeda, H.; K. Kumagai \& N. Ishida: Characterization of neocarzinostatin. J. Antibiotics 19: 253 259, 1966

11) MAEdA, H.: Succinylation of an antibiotic protein, neocarzinostatin. in Abstract, page 454; Colloquium D. of 9th International Congress of Biochemistry (Stockholm, 1973)

12) Samy, T.S.A.; M. Atleyi, H. Maeda \& J. MeIENHOFER: Selective tryptophan oxidation in antitumor protein neocarzinostatin and effects on conformation and biological activity. (To be published) 